\title{
Obituary
}

\section{Anti-spit tobacco crusader Bill Tuttle}

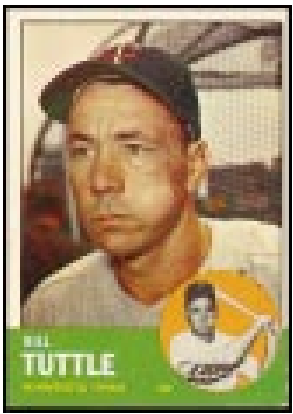

Figure 1 One of several baseball cards that showed Bill Tuttle with a cheek full of spit tobacco.
Former major-league baseball player and antispit tobacco champion Bill Tuttle died on 27 July 1998 in Anoka, Minnesota, after a long battle with oral cancer. $\mathrm{He}$ was $69 . \mathrm{He}$ is survived by wife Gloria; their three daughters Debra Heyers, Kimberly Oliver, and Cindy Chase; four children from a previous marriage-Patricia Bradley and Becky Porter, Robert, and James; and 17 grandchildren.

Tuttle was an outfielder, and is still remembered for his theatrical catches while playing 11 seasons with the Detroit Tigers, Kansas City Athletics, and the Minnesota Twins. His legacy, however, will extend far beyond the ballpark. Until his last days, Tuttle, along with his wife Gloria, was an outspoken critic of his nemesis: spit tobacco. He was a living example of the consequences of tobacco addiction, and he worked hard to exploit that example to the fullest.

Tuttle was born on 4 July 1929, in Farmington, Illinois. He played for Bradley University before being scouted by the Detroit Tigers. $\mathrm{He}$ bounced around in the minor leagues for four years before making it to "the bigs". It wasn't until Tuttle started in the major league that he began chewing tobacco. After an injury put Tuttle on the bench for longer than usual, a teammate offered Bill a chew, "just to pass the time". Several of Tuttle's baseball cards bear the image of a young, handsome player, a cheek bulging with spit tobacco (figure 1).

Thirty-eight years later Bill had a bulge in his cheek that wouldn't go away. Doctors diagnosed it as a large buccal cancer. The tumour was so large that it came through his cheek and extended through the skin. Doctors scheduled Bill for immediate surgery on 11 November

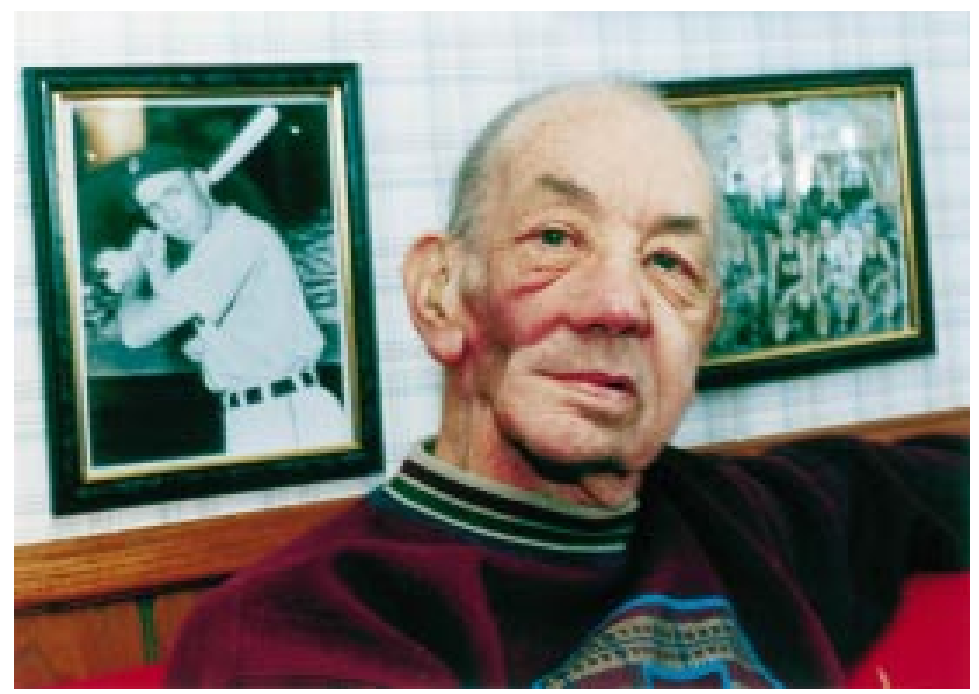

Figure 2 Bill Tuttle, after surgery for mouth cancer caused by chewing tobacco. Photo by Sara Sevans, reprinted with permission of the "St Paul (Minnesota) Pioneer Press".
1993. The procedure was to take two and a half hours; it lasted for more than 13. After more than five operations spanning more than 50 hours, Bill had lost much of his face, including his jaw, teeth, and right cheek. To make up for lost facial tissue doctors took patches of skin and muscle from other areas and tried to recreate his face (figure 2). "He still looked like a dried-up apple," said Gloria. Throughout the five operations and 51 treatments of radiation therapy, the Tuttles had no medical insurance. Bill had played ball in a different era, one without astronomical contracts and endorsements.

Joe Garagiola, former major league catcher and broadcast announcer, is the head of the Baseball Assistance Team, which helps former players like Bill. Garagiola called the Tuttles on Christmas Eve 1993 and told them his organisation would cover all medical expenses. In return, he asked for a favour.

Garagiola is also the chair of the National Spit Tobacco Education Program, which aims to raise awareness about this lethal product. "Everyone talks about smoking, smoking, smoking", said Garagiola. "I say: tobacco is tobacco is tobacco." One of Garagiola's target audiences is major league baseball, where almost $40 \%$ of the players use spit tobacco. He asked Bill and Gloria for help. Though Bill was not far from the end of his life, a new era emerged for him and Gloria.

The Tuttles went on a whirlwind tour of major league clubhouses during 1994 spring training. Garagiola remembers the initial visits with some clubs. "We weren't exactly given the red carpet in the early days", recalls Garagiola. Some players would continue to spit and chew in defiance as Garagiola spoke. But when he introduced Bill, the attitude changed. People have said repeatedly that Bill's physical presence was his story. His face alone was enough for some of the players to stop chewing and spitting while he talked. As he continued with his story, Garagiola remembers seeing players looking for a way to take out their chew.

Bill's message was simple: if you chew, you may end up looking like me. He urged players to remember that they are role models to young people. He pleaded with them to keep chew out of camera range. Gloria then spoke of the immense toll Bill's illness had taken on the family, the late nights, the hours waiting during surgery and the uncertain future.

Gloria also sent a letter to all the baseball wives elaborating on her story. "I am watching the man I love die," she wrote. "It is the most difficult thing I have ever done in my entire life. ... Bill Tuttle today is not the rifle-armed Bill Tuttle who patrolled center field for ten seasons. . . Today, Bill can't even raise his 
right arm straight up. . . . Have you ever tried cooking for a fussy eater? Well, try cooking for a man who can't taste and has no teeth. Try eating out with a man who drools or drops his food because he can't open his mouth far enough for the fork to fit in. . . . It is horrible to see this once strong, virile man reduced to this condition."

Even in a weakened state, Bill was a tireless crusader against spit tobacco. $\mathrm{He}$ spoke to major and minor league teams, and to students of all ages. He lobbied his state legislators to vote against tobacco-friendly bills. He spoke to anyone who would listen. Immense guilt and a sense of responsibility drove him. Bill never dreamed what he would put his family through with his illness. Bill was particularly haunted by the thought that his role-modelling of spit tobacco could have prompted young people to start using it. Until the very end, Bill sought to undo the harm he felt he had caused, unable to accept that his suffering and perseverance were penance enough. Eventually, Bill lost most of his voice. He communicated with pen and paper. Two days before he died, he wrote Gloria a note: "I know what I did was wrong and I'm so sorry I hurt everybody. But maybe I can show them how sorry I am by teaching other people."

JANE IMHOLTE

Association for Nonsmokers-Minnesota,

2395 University Avenue West, Suite 310,

St Paul, Minnesota 55114, USA;

jimholte@usinternet.com

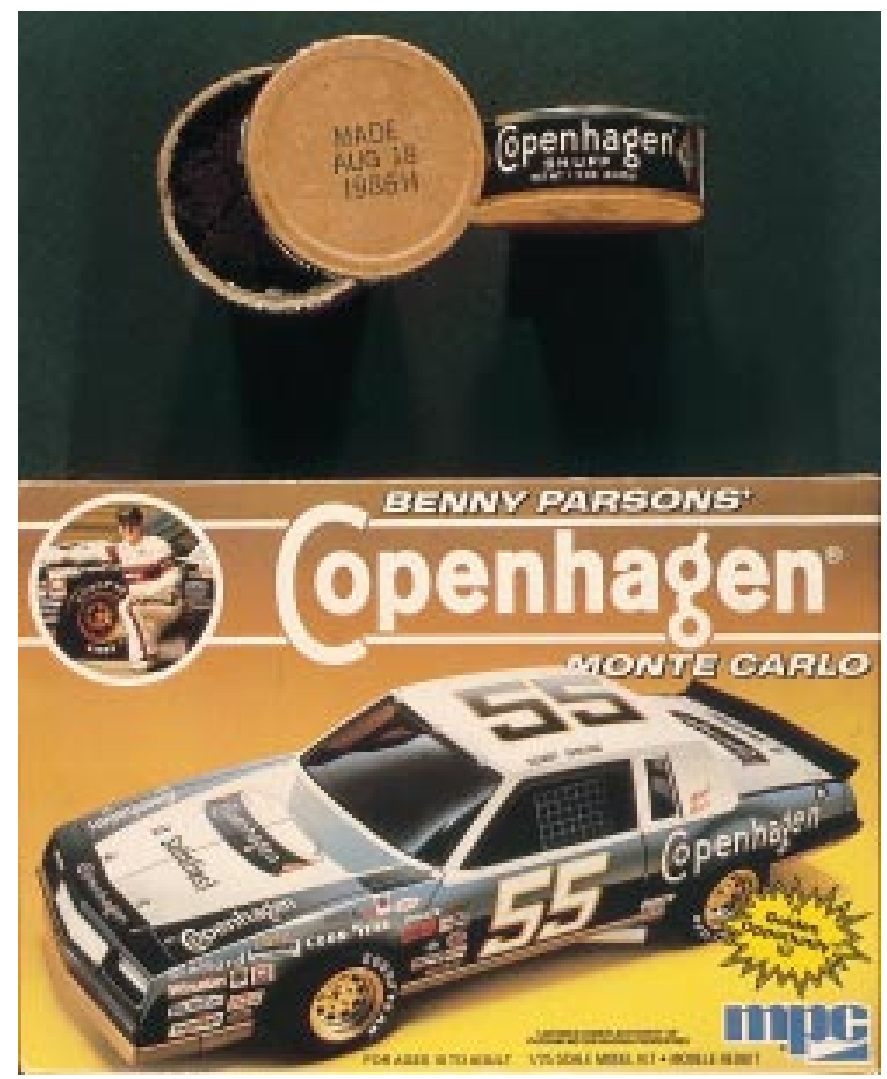

A toy car "sponsored" by Copenhagen snuff. The toy was manufactured by The Ertl Company in Dyersville, Iowa, and was sold in toy stores throughout the United States. The box indicates that the product is "for ages 10 to adult". Similar toy cars were emblazoned with the names of other smokeless tobacco products, including Skoal Bandits and Chattanooga Chew (see "Alaska Medicine", fan/Feb/March 1996. pp 43-8, for a photograph of the Skoal Bandits toy car). 